\title{
PEMERATAAN ENERGI GELOMBANG LAUT DENGAN SISTEM BERPISTON AKSI GANDA
}

\author{
I Made Adi Sayoga, I Made Nuarsa \\ Dosen Jurusan Teknik Mesin Universitas Mataram NTB, Jl. Majapahit Nomor 62
}

\begin{abstract}
Abstrak
Semakin menipisnya cadangan minyak dunia menyebabkan harga bahan bakar minyak (BBM) terus melambung. Kondisi ini menyebabkan masalah yang serius yang perlu diatasi. Potensi energi yang diperbaharui seperti : energi angin, matahari dan gelombang laut perlu segera dilirik walaupun mungkin sudah terlambat. energi potensial dan kinetik yang terkandung pada gelombang laut dapat dikonversikan untuk pemanfaatan tenaga listrik maupun pompa air bersih dan irigasi.

Tujuan penelitian adalah untuk memanfaatkan potensi energi gelombang untuk dikonversi menjadi tenaga listrik. Adapun manfaat penelitian ini adalah akan diperoleh metode dan sumber energi alternative yang ramah lingkungan serta tidak membutuhkan bahan bakar minyak. Energi alternatif ini ditunggu pemanfaatannya oleh masyarakat.

Kegiatan penelitian diawali dengan studi literatur untuk mengkaji penelitian yang terdahulu, mencari perumusan dengan teori yang ada. Hasil studi literatur dilanjutkan membuat disain atau rancangan alat dengan perhitungan-perhitungan. Perhitungan mengacu pada prinsip pemanfaatan energi gelombang laut semaksimal mungkin. Dari perhitungan tersebut sangat menentukan langkah selanjutnya seperti pembuatan bentuk, pemilihan bahan, menentukan alat ukur dan model pengukuran.

Konversi energi dari gelombang ke piston yang paling efektif terjadi pada saat pelampung (piston) diberikan beban $W$ setengah dari Fa Total ( $W=F a / 2$ total) dibandingkan pada saat tak berbobot $(W=0$ ) maupun pada saat piston diisi penuh ( $W=F a$ total).

Dari hasil pengujian ternyata prototype pemerataan gelombang laut dengan sistem aksi ganda mampu menghasilkan energi listrik. Pada saat gelombang naik, energi gelombang menekan tuas melalui pelampung yang selanjutnya memutar roda gigi yang telah terhubung dengan generator listrik. Sedangkan pada saat gelombang turun roda gigi juga berputar akibat berat pelampung yang telah diiisi pemberat air.
\end{abstract}

Kata Kunci : energi, gelombang laut, piston aksi ganda, torsi, energi listrik

\section{PENDAhUluan}

Gelombang laut menyimpan energi yang sangat besar dan belum termanfaatkan secara maksimal. Pemanfaatan gelombang laut untuk dikonversikan menjadi energi yang bermanfaat bagi manusia terus diteliti oleh peneliti luar negeri maupun peneliti dalam negeri. Energi potensial dan kinetik yang terkandung pada gelombang laut dapat dikonversikan untuk pemanfaatan tenaga listrik maupun pompa air bersih dan irigasi.

Pembangkit tenaga gelombang untuk tenaga listrik dengan sistem single piston dengan variasi bentuk yaitu segi empat, bulat, silinder dan oval telah diteliti oleh Reza (2003). Ternyata piston segi empat dan piston cilinder (single piston single action) yang mempunyai gaya eksitasi yang paling besar. Namun, dapat dipastikan bahwa dengan system aksi ganda (double action) gaya eksitasi yang dihasilkan menjadi semakin besar.

Apakah potensi tenaga gelombang laut sebagai sumber energi alternatif selain minyak bumi bisa menghasilkan tenaga listrik yang sesuai?. Ada banyak penelitian yang telah dilakukan untuk menggali potensi gelombang laut tersebut.

Azhar dkk (2000), meneliti mekanika pengalih dan penyimpan energi gerak rambang air laut sebagai pembangkit daya gerak kapal. Penelitian ini menghasilkan, pemanfaatan fluktuasi tekanan permukaan dirubah dengan sistem silender apung menjadi gaya translasi. Gaya translasi tersebut dapat akan dimanfaatkan sebagai gaya penggerak kapal dengan tambahan mekanisme poros ongkol. Prototipe pengalihan energi gelombang laut dengan dua pelampung yang dihubungkan oleh batang dibuat oleh Azhar (2003). Akibat 
perbedaan ketinggian permukaan air laut menyebabkan bergeraknya kedua posisi pelampung. Pergerakan kedua posisi pelampung akan menyebabkan pergerakan sistem roda gigi yang sudah disearahkan. Penelitian ini menghasilkan putaran 8000 rpm dan daya maksimum $5 \mathrm{~kW}$. Selanjutnya tahun pada tahun yang sama, diteliti pompa pneumatic system injeksi tenaga gelombang laut dengan kerangka statis (tiang pancang). Penelitian ini menghasilkan udara bertekanan tinggi 5 bar untuk mengerakan pompa irigasi.

Tahun 2004, meneliti pompa tekanan tinggi tenaga gelombang laut kerangka dinamis. Akibat perbedaan tinggi permukaan air laut menyebabkan pelampung bergerak naik turun. Pergerakan ini menyebabkan tuas penghubung pompa menggerakan pompa torak. Pergerakan ini menghasilkan 0,2 liter/detik efisiensi 0,30,7 . Jika dianalisa sistem pompa kerangka dinamis masih banyak kelemahan yaitu sudut gerak gaya yang berubah-rubah akibat ikut naik turunnya kerangka pompa. Analisa ini juga menyebabkan efisiensi dan efektifitas pompa masih kurang.

Pembangkit tenaga gelombang dengan sistem single piston single action pada 4 bentuk piston (Reza, 2003) ternyata piston segi empat dan piston cilinder yang mempunyai gaya eksitasi yang paling besar. Sistem dengan piston aksi ganda diduga mampu menyerap energi gelombang secara kontinyu karena pada gelombang naik energi disuplai oleg gaya apung piston jika gelombang turun maka energi akan disuplai oleh berat piston. Pengujian meliputi menentukan putaran dan torsi maksimum.

\section{TUJUAN PENELITIAN}

Tujuan dari penelitian ini adalah untuk memanfaatkan potensi tenaga gelombang laut untuk dikonversi menjadi tenaga listrik.

\section{MANFAAT PENELITIAN}

Jika penelitian ini akan memberikan hasil yang memuaskan, maka akan diperoleh metode dan sumber energi alternatif yang ramah lingkungan serta tidak membutuhkan bahan bakar minyak. Energi alternative ini sangat ditunggu pemanfaatannya oleh masyarakat.

\section{METODE PENELITIAN}

Penelitian ini menggunakan metode eksperimental dengan dua tahap percobaan yaitu: Tahun 2008 yaitu pengujian bentuk piston silinder pada sistem satu piston aksi ganda (double action) untuk mendapatkan putaran dan torsi maksimum. Tahun 2009 membuat prototype pembangkit listrik energi gelombang laut sistem satu piston aksi ganda (Single piston double action).

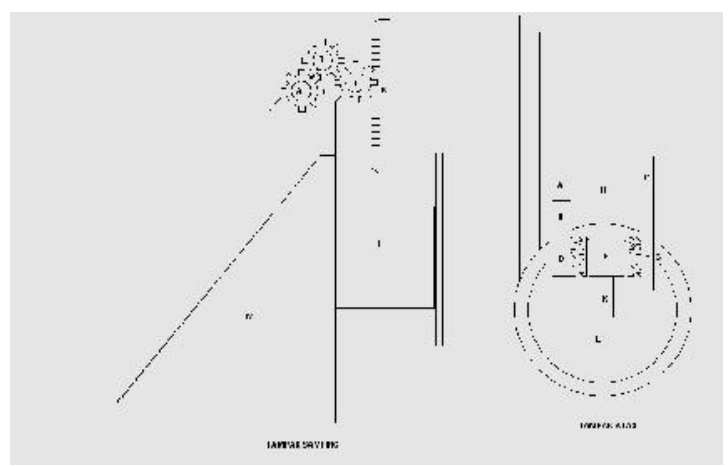

Gambar 1. Skema Alat Penangkap Gelombang laut Sistem Piston Aksi Ganda

Keterangan Gambar 1 :
$A, B, C, D, E$ dan $F$ : roda gigi
$\mathrm{M}$
$\mathrm{L}$
: kerangka
: piston
: gigi batang
: poros output
: poros input

\section{Uraian Kerja Sistem}

Gaya eksitasi yang diakibatkan tekanan gelombang akan menyebabkan piston $L$ bergerak naik turun terhadap silinder relnya. Gerak translasi piston $\mathrm{L}$ tersebut akan diteruskan oleh gigi batang transmisi $\mathrm{K}$ yang kangsung memutar roda gigi $\mathrm{E}$. Ketika piston $\mathrm{L}$ bergerak konstan akibat tekanan gelombang, batang gigi $\mathrm{K}$ akan memutarkan roda gigi $\mathrm{E}$ pada arah berlawanan jarum jam (gambar tampak samping), sekaligus menggesernya untuk berhubungan dengan roda gigi $D$, yang kemudian ikut berputar bersama roda gigi E. Putaran tersebut akan diteruskan ke roda gigi $A$ melalui roda gigi $B$. Sehingga putaran akhir pada poros $\mathrm{H}$ adalah berlawanan arah jarum jam.

Kemudian ketika piston $L$ yang memiliki berat $\mathrm{W}$ turun akibat kehilangan gaya apungnya batang transmisi $\mathrm{K}$ akan memutar roda gigi $E$ searah jarum jam dan menggesernya berhubungan dengan roda gigi $F$ (bergesernya roda gigi $F$ secara aksial tersebut, karena adanya ulir pada roda gigi $F$ dan poros $G$ ) secara simultan hubungan roda gigi $D$ dan roda gigi $D$ 
terlepas. Dengan terhubungkannya roda gigi $F$ dan $E$ maka roda gigi $F$ juga ikut berputar searah jarum jam, akibatnya roda gigi $\mathrm{C}$ berputar berlawanan jarum jam. Dengan demikian gerak turun dan naiknya piston $L$ akan tetap menghasilkan output putaran yang searah pada poros $\mathrm{H}$.

\section{Besar Daya Listrik}

Besarnya daya atau tenaga yang dikeluarkan oleh sumber energi listrik terhadap pemakainya dinyatakan dengan rumusan dasar elektronikan berikut ini (Warsito, 1978)

\section{Dimana \\ $P:$ I $x \vee$ (Watt) \\ I : Kuat arus (Ampere) \\ $\mathrm{V}$ : Tegangan listrik (Volt)}

Tegangan listrik $(\mathrm{V})$ yang dihasilkan adalah konstan selama sumber energi listrik tersebut masih baik. Parameter yang berubah adalah kuat arus (I), dimana hal ini tergantung dari kondisi baterry. Jika penggunaan energi listrik ini digunakan dalam waktu yang lama, maka kuat arus (I) akan berkurang. Kuat arus dan daya atau tenaga $(P)$ adalah hubungan linier dan jika kuat arus berkurang maka daya dihasilkan juga berkurang. Tegangan energi listrik bervariasi tergantung kapasitasnya, accu (6 V, $9 \mathrm{~V}, 12 \mathrm{~V}, 24 \mathrm{~V}$ dll). Kuat arus dari accu tergantung dari besarnya sumber energi listrik tersebut, sehingga daya atau tenaga (Watt) yang dibutuhkan untuk lampu penerangan sesuai dengan kapasitas sumber energi listrik.

Sistem pelampung ini dapat menghasilkan daya hanya dengan mengapungkannya di permukaan lautan yang bergelombang. Sistem ini diletakkan kurang lebih satu atau dua mil laut dari pantai, yang disebut sebagai permanent magnet linear generator buoy. Koil elektrik mengelilingi batang magnet di dalam pelampung dan koil tersebut ditempelkan pada pelampung, batang magnet dikaitkan ke dasar laut. Saat ombak mencapai pelampung, maka pelampung tersbut akan bergerak naik dan turun secara relatif terhadap batang magnet yang menimbukan beda potensial dan listrik dibangkitkan.

\section{HASIL DAN PEMBAHASAN}

Pelaksanaan

penelitian

pemanfaatan energi gelombang laut untuk pemanfaatan Energi listrik dilakukan di pantai Tanjung Karang, Mataram.
Pengambilan data dilakukan pada pagi, siang dan sore hari. Pada Tabel 5.1 diperlihatkan data pada saat $\mathrm{Ws}=\mathrm{Fa}$.

Tabel 5.1 Data ketika silinder menerima gaya apung (naik)

\begin{tabular}{|c|c|c|c|c|c|c|}
\hline No & $\begin{array}{c}\mathbf{H 1} \\
\mathbf{( c m )}\end{array}$ & $\begin{array}{c}\mathbf{H 2} \\
\mathbf{( c m}\end{array}$ & $\begin{array}{c}\mathbf{T ~ f} \\
\text { (detik) }\end{array}$ & $\begin{array}{c}\mathbf{I} \\
\text { (Ampere) }\end{array}$ & $\begin{array}{c}\mathbf{V} \\
\text { (Volt) }\end{array}$ & $\begin{array}{c}\text { Ef } \\
\text { (Watt) }\end{array}$ \\
\hline 1 & 72 & 67 & 1,13 & 41 & 13,7 & 561,7 \\
\hline 2 & 63 & 59 & 1,35 & 31 & 13,2 & 409.2 \\
\hline 3 & 45 & 41 & 1,83 & 22 & 12,7 & 279,4 \\
\hline 4 & 57 & 52 & 1,55 & 27 & 13,1 & 353,7 \\
\hline 5 & 37 & 34 & 1,97 & 17 & 12,2 & 207,4 \\
\hline 6 & 68 & 62 & 1,21 & 35 & 13,4 & 469 \\
\hline 7 & 41 & 37 & 1,75 & 20 & 12,5 & 250 \\
\hline 8 & 76 & 70 & 1,08 & 43 & 13,7 & 589,1 \\
\hline 9 & 52 & 48 & 1,60 & 25 & 12,9 & 322,5 \\
\hline 10 & 81 & 77 & 0,91 & 46 & 13,8 & 634,8 \\
\hline
\end{tabular}

Keterangan:

$\mathrm{H} 1$ : Tinggi gelombang (cm)

$\mathrm{H} 2$ : Tinggi gerak selinder $(\mathrm{cm})$

I : Kuat arus yg mengalir $(A)$

$\mathrm{V}$ : Tegangan listrik yg timbul (volt)

Tf : Waktu gerak silinder naik (detik)

Ef : Energy akibat gaya apung (Watt)

Tabel 5.2 Data ketika silinder menerima gaya berat (Turun)

\begin{tabular}{|l|c|c|c|l|l|l|}
\hline No & $\begin{array}{c}\text { H1 } \\
\text { (cm) }\end{array}$ & $\begin{array}{c}\text { H2 } \\
\text { (cm) }\end{array}$ & $\begin{array}{c}\text { Tg } \\
\text { (detik) }\end{array}$ & $\begin{array}{c}\text { I } \\
\text { (Ampere) }\end{array}$ & $\begin{array}{c}\text { V } \\
\text { (Volt) }\end{array}$ & $\begin{array}{c}\text { Eg } \\
\text { (Watt) }\end{array}$ \\
\hline 1 & 72 & 67 & 1,32 & 36 & 13,7 & 493,2 \\
\hline 2 & 63 & 59 & 1,62 & 28 & 13,0 & 364 \\
\hline 3 & 45 & 41 & 1,94 & 20 & 12,3 & 246 \\
\hline 4 & 57 & 52 & 1,73 & 24 & 12,9 & 309,6 \\
\hline 5 & 37 & 34 & 2,21 & 14 & 12,0 & 168 \\
\hline 6 & 68 & 62 & 1,85 & 33 & 13,2 & 435,6 \\
\hline 7 & 41 & 37 & 2,13 & 18 & 12,2 & 219,6 \\
\hline 8 & 76 & 70 & 1,28 & 38 & 13,7 & 520,6 \\
\hline 9 & 52 & 48 & 1,73 & 22 & 12,7 & 279,4 \\
\hline 10 & 81 & 77 & 1,25 & 34 & 13,7 & 465,8 \\
\hline
\end{tabular}

Keterangan:

$\mathrm{H} 1$ : Tinggi gelombang $(\mathrm{cm})$

$\mathrm{H} 2$ : Tinggi gerak selinder $(\mathrm{cm})$

I : Kuat arus yg mengalir (A)

$\mathrm{V}$ : Tegangan listrik yg timbul (volt)

$\mathrm{Tg}$ : Waktu gerak silinder turun (detik)

Eg : Energy akibat gaya berat/gravitasi (Watt) 


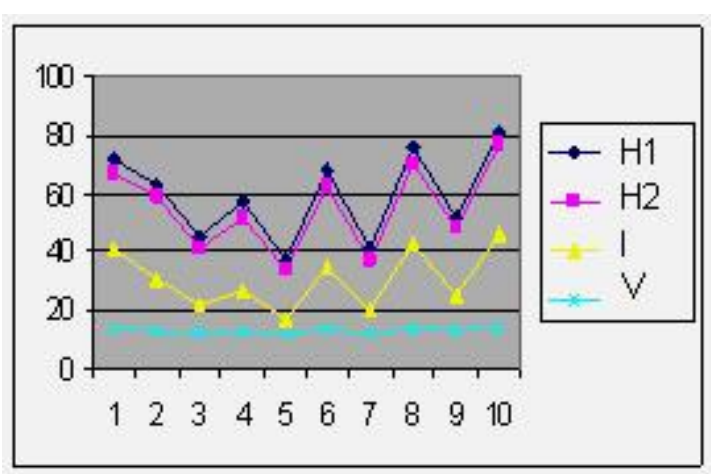

Grafik 1. Hubungan antara tinggi gelombang, tinggi gerak silinder, kuat arus dan tegangan listrik akibat gaya apung

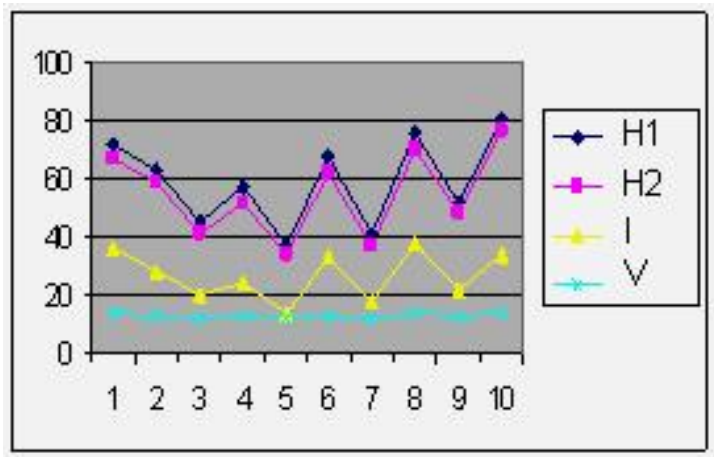

Grafik 2. Hubungan antara tinggi gelombang, tinggi gerak silinder, kuat arus dan tegangan listrik akibat gaya berat

\section{Pembahasan}

Konversi energi dari gelombang ke piston yang paling efektif terjadi pada saat pelampung (piston) diberikan beban $\mathrm{W}$ setengah dari $\mathrm{Fa}$ Total $(\mathrm{W}=\mathrm{Fa} / 2$ total) dibandingkan pada saat piston tak berbobot $(\mathrm{W}=0)$, maupun pada saat piston diisi penuh ( $\mathrm{W}=\mathrm{Fa}$ total). Hal ini terjadi karena pada saat piston $(\mathrm{W}=0)$ atau ( $\mathrm{W}=\mathrm{Fa}$ total) gaya eksitasi sangat besar tapi ditransfer semua oleh piston ke system transmisi dan terjadi dalam rentang waktu yang sangat singkat, akibatnya tahanan kelembaman dengan gesekan roda-roda gigi transmisi yang di akselerasi oleh piston sangat besar. Hal ini menyebabkan hanya sebagian kecil saja energi gelombang yang mengolah energi mekanis pada roda gigi output, setelah itu lewat begitu saja.

Sedangkan pada $\mathrm{W}=1 / 2 \mathrm{Fa}$, proses konversi energi berlangsung lebih lama, yaitu pada saat piston turun akibat $\mathrm{W}$ dan pada saat piston naik akibat $\mathrm{Fa}$, hal ini menyebabkan kerugian energi gelombang akibat factor bypass dapat dikurangi sehingga energi yang berhasil ditransmisikan ke roda gigi output menjadi lebih besar.

Energi yang ditransmisikan ke roda gigi akan diteruskan ke generator listrik. Akibat putaran roda gigi generator listrik juga ikut berputar. Konversi energi elektromekanik adalah mekanik ke listrik dan dari bentuk listrik ke makanik Berlangsung pada sistem tenaga melalui elektromagnetik yang disebut generator dan motor.

Medan magnet sangat berperan dalam konversi energi. Dalam Generator energi mekanik dapat dirubah menjadi energi listrik melalui medan magnet. Dalam motor listrik energi listrik dapat dikonversikan menjadi energi mekanik. Dari sisi elektris medan magnet mampu mengimbaskan tegangan pada konduktor.Dari sisi mekanis medan magnet sanggup mengasilkan kopel atau gaya.

Konversi energi baik energi listrik menjadi energi mekanik (motor) maupun sebaliknya energi mekanik menjadi energi listrik (generator) berlangsung melalui medan magnet. Energi yang diubah dari sistem satu ke sistem lainya, sementara disimpan dalam medan magnet kemudian dilepas menjadi energi sistem lainya. Medan magnet selain berfungsi sebagi penyimpan energi juga sekaligus sebagai medium untuk mengkopel proses perubahan energi.

Dari hasil pengujian energi listrik yang dihasilkan oleh prototype pembangkit listrik tenaga gelombang laut aksi ganda mampu menghasilkan daya listrik baik pada saat gelombang naik maupun turun. Pada saat gelombang naik piston akan menekan roda gigi sehingga berputar yang diteruskan kegeneraor listrik. Sedangkan pada saat gelombang turun generator berputar akibat berat piston yang telah diisi beban air.

\section{KESIMPULAN DAN SARAN}

\section{a. Kesimpulan}

Berdasarkan data dan analisa data yang diperoleh dalam penelitian ini, maka dapat disimpulkan bahwa :

1. Piston mampu menyerap energi gelombang laut yang mengkonversi energi gelombang menjadi energi mekanis penggerak roda gigi. 
2. Penyerapan energi terjadi pada saat gelombang naik dan gelombang turun

3. Energi listrik yang dihasilkan oleh prototype rancangan mampu menghasilkan energi listrik pada saat gelombang naik maupun turun

\section{b Saran}

Untuk menyempurnakan penelitian penangkap energi gelombang laut yang akan datang, maka dapat digunakan sebagai masukan :

1. Karena energi yang dihasilkan tidak konstan sepanjang waktu atau ada kalanya roda gigi akan berhenti karena gelombang laut tenang maka perlu dirancang alat penyimpan energi listrik.

\section{DAFTAR PUSTAKA}

Anonim. 1995 "Penelitian Spektrum Gelombang Laut Indonesia di Perairan Selat Makassar". Proyek Pembangunan dan Pengoperasian Sarana Penunjang Kelautan BPP Teknologi, Surabaya,

Azhar, 1999, Pengaruh pembebanan pada pelampung kubus terhadap efektifitas tangkapan energi gelombang laut, Penelitian Swadana.

Azhar, 2000, Perencanaan mekanika pengalih penyimpanan energi gerak rambang air laut sebagai pembangkit daya penggerak kapal, Penelitian Swadana

Azhar, 2000, Sistem pompa tekanan tinggi tenaga gelombang laut kerangka dinamis, Penelitian Swadana.
Azhar, 2000, Mesin pengalih gelombang laut menjadi energi listrik, Penelitian Swadana.

Azhar, 2001, Sistem penggerak kapal laut bertenaga gelombang laut dengan prinsip fluktuasi tekanan, Penelitian Swadana,

Bambang Triatmodjo,1999." Teknik Pantai" Beta Offset, Yogyakarta,

De Fretes, E.R., 2001 "Analisis Perilaku Sistem Penambatan Bagan Penangkap Ikan", Thesis Program Pasca Sarjana ITS, Surabaya.

Eliza R, 2003, Disain lampu otomatis untuk perlengkapan bagan milik nelayan yang beroperasi diperairan Maluku Tenggara Barat, Laporan Pengabdian Masyarakat Vucer.

Eliza R, 2003, Disain alat pembangkit listrik tenaga gelombang untuk bagan dan rumpon yang beroperasi di maluku, Laporan Penelitian Dosen Muda

Molland, A.F. \& Taunton, D.J. 1999 "Methods For Assessing the Seakeeping Performance of Competing High Speed Vessel Design", papers , International Conference Hydrodynamics of High Speed Craft, London.

Rawson, K.J. and Tupper, E.C, 1984.,"Basic Ship Theory", Volume $2,3^{\text {rd }}$ edition, Longman Group Ltd, London, 